Article

\title{
Vegetation Cover Drives Arthropod Communities in Mediterranean/Subtropical Green Roof Habitats
}

\author{
Ibrahim N. A. Salman * and Leon Blaustein \\ Department of Evolutionary and Environmental Biology, Institute of Evolution, Faculty of Natural Sciences, \\ University of Haifa, Haifa 3498838, Israel; leon@research.haifa.ac.il \\ * Correspondence: isalma04@campus.haifa.ac.il
}

Received: 24 October 2018; Accepted: 13 November 2018; Published: 15 November 2018

\begin{abstract}
Worldwide, urban areas are expanding both in size and number, which results in a decline in habitats suitable for urban flora and fauna. The construction of urban green features, such as green roofs, may provide suitable habitat patches for many species in urban areas. On green roofs, two approaches have been used to select plants-i.e., matching similar habitat to green roofs (habitat template approach) or identifying plants with suitable traits (plant trait approach). While both approaches may result in suitable habitats for arthropods, how arthropods respond to different combinations of plants is an open question. The aim of this study was to investigate how the structural complexity of different plant forms can affect the abundance and richness of arthropods on green roofs. The experimental design crossed the presence and absence of annuals with three Sedum sediforme (Jacq.) Pau (common name: stonecrops) treatments-i.e., uniformly disrupted Sedum, clumped disrupted Sedum, and no Sedum. We hypothesized that an increased structural diversity due to the coexistence of different life forms of plants on roofs is positively related to the abundance and richness of arthropods. We found that arthropod abundance and richness were positively associated with the percent of vegetation cover and negatively associated with substrate temperature. Neither arthropod abundance nor richness was influenced by the relative moisture of substrate. We also found that arthropod abundance and richness varied by green roof setups (treatments) and by seasonality. Arthropod abundance on green roofs was the highest in treatments with annuals only, while species richness was slightly similar between treatments containing annuals but varied between sampling periods. This study suggests that adding annuals to traditional Sedum roofs has positive effects on arthropods. This finding can support the development of biodiverse cities because most extensive green roofs are inaccessible to the public and can provide undisturbed habitat for several plant and arthropod species.
\end{abstract}

Keywords: green roof; biodiversity; succulents; vegetation cover

\section{Introduction}

Worldwide, urban areas are expanding both in size and number. For instance, since the early 1990s, there has been an approximate 2 billion people increase [1]. This rapid urbanization is associated with an increase in both natural resource use and habitat fragmentation, thus leading to a decrease in alpha diversity. Preserving habitat diversity is practically important within urban areas, considering that cities play a crucial role for native species $[2,3]$.

For decades, conservation biologists have focused primarily on the protection of natural ecosystems and have placed little importance on urban areas or urban biodiversity [4]. To date, most studies on wildlife in cities have focused on birds [5,6]. However, few studies have focused on arthropods [7-9]. Invertebrates, in general, comprise approximately $80 \%$ of all described species [10], which makes them an ideal research topic. 
Arthropod communities are affected by several factors, including habitat heterogeneity [11] and habitat productivity-e.g., plant biomass and vegetation cover [12]. The relationship between vegetation structure, cover, and arthropod communities is important, as the structure of arthropod communities may be influenced by the conditions created by the plant community [8]. However, in many urban habitats, vegetation cover and plant biomass are disrupted, prominently by human interference. By improving some of these conditions in urban habitat, arthropods may be enhanced, and their response may be affected not only on the local scale but also on a larger scale. This can be achieved through the construction of urban green features, such as green walls [13] or green roofs [14-16].

The urban green features known as green roofs might become a biodiversity hotspot in cities. Williams et al. [17] showed that green roofs have greater species diversity than conventional roofs and can provide habitat for generalists and some rare species. Green roofs consist of several layers and mainly depend on using shallow substrate rather than deep substrate [18], which can provide an unstable environment for several plant species due to a tendency toward temperature fluctuations in the substrate [19]. Therefore, it is vital to select plants that can potentially survive and tolerate high temperatures, in addition to providing a greener space for longer periods of time. Traditionally, two approaches have been used to select plants on green roofs-i.e., matching similar habitat to green roofs (habitat template approach) [20] or identifying plants with suitable traits (plant trait approach) [21], such as succulent plants. While both approaches may result in suitable habitats for arthropods, how arthropods respond to different combinations of plants is an open question. Among these candidate plants, Sedum (common name: stonecrops) species are considered the most recommended and successful candidate [22,23]. Sedum species have the ability to withstand water deficiencies, they have shallow roots, and they are also able to tolerate extreme temperatures and high winds. In addition, Sedum exhibits CAM photosynthesis [24]—whereby transpiration is reduced or inhibited during the day so that water loss is minimized by low rates of transpiration-and/or drought avoidance, which allows for their survival in green roof systems. However, this species is unable to avoid convective heat transfer under its leaves and, consequently, it has a low thermal resistance value [25].

Other plant species can also be used successfully on green roofs, including several annual species, for example, Trifolium stellatum L. (common name: starry clover), Triticum dicoccoides (Koern. ex Asch. \& Graebn.) Schweinf. (emmer wheat), Malva parviflora L. (cheeseweed), Hordeum glaucum Steud. (wall barley), and Avena sterilis L. (sterile oat), in addition to many others [26,27]. Vasl et al. [28] showed that Sedum interacted with annuals, reducing substrate temperature, and the presence of annuals reduced substrate moisture, which may directly affect the arthropod community structure on green roofs. In another study, Butler and Orians [29] showed that Sedum may facilitate the growth of other species, but only during the summer when these species face drought conditions. Arthropods, however, may have limited biodiversity value on Sedum-based green roofs compared to other vegetation types because of their limited flowering period and structural diversity [30]. Kadas [7], for instance, detected greater species abundance and diversity of arthropods on Sedum roofs compared to 'biodiverse' roofs, but acknowledged that the biodiverse roofs were only 1 year old. In another study, Heinze [31] compared combinations of various Sedum species, grasses, and herbaceous perennials planted at two substrate depths in simulated roof platforms. The Sedum species outperformed the other taxa, except in consistently moist substrates deeper than $10 \mathrm{~cm}$. Many macroinvertebrates like springtails, millipedes, and centipedes have been found colonizing the substrates of Sedum-based green roofs, likely because they provide shade and moisture on rooftops where these resources are limited [32].

Relatively few studies have been conducted in Mediterranean subtropical habitats, especially in urban contexts [33,34]. Green roofs can provide a suitable habitat for arthropods to maintain a minimal viable population size and reduce their extinction rates [35]. In this study, we aim to investigate how the structural complexity of different plant forms can affect the abundance and richness of arthropods on green roofs. We sampled arthropods from a green roof at the University of Haifa, Israel. 
We hypothesized that an increased structural diversity due to the coexistence of different life forms of plants on roofs is positively related to the abundance and richness of arthropods.

\section{Methods}

\subsection{Experimental Design}

This study is part of a larger project $[36,37]$ to study various aspects of arthropod community structure, stormwater management, and pollution abatement on green roofs. For this objective, we used experimental modules on a roof at the University of Haifa. The modules were built on 24 November 2013. Thirty separate experimental modules (length $\times$ width $\times$ height: $100 \times 100 \times 20 \mathrm{~cm}$ ) with wooden frames lined with an impermeable plastic root barrier sheet (Wepelen ${ }^{\circledR}$ Aqua Tec, RKW, Germany) were embedded into the tuff substrate on a $2^{\circ}$ slope. The undersides of all modules were covered with a protective polypropylene geotextile layer (Stratum $30 \mathrm{~mm}$, Pavitex, Italy) both beneath and above the impermeable plastic sheets to protect the sheet from physical damage. One drainage point per module was situated $5 \mathrm{~cm}$ above the lower-most corner of the module. A small $10 \times 10 \mathrm{~cm}$ 'cushion' made of a coated non-woven root barrier sheet (Plantex ${ }^{\circledR}$ Gold, DuPont, Luxembourg) containing large tuff (highly porous and vesicular volcanic rock, also referred to as lava rock) $(4-8 \mathrm{~mm})$ was placed on the inner side of the drainage unit to filter runoff water and prevent clogging of drainage points. Substrate was mixed in situ and contained $10 \%$ peat, $10 \%$ compost, $10 \%$ tuff (diameter $-0-8 \mathrm{~mm}$, quarried by 'Tuff Merom Golan', Merom Golan, Israel), and 70\% processed perlite (diameter $-0.6 \mathrm{~mm}$, imported amorphous volcanic glass, produced by 'Agrical', HaBonim, Israel).

The experimental design crossed the presence and absence of annuals with three S. sediforme treatment levels: uniformly distributed Sedum, clumped distributed Sedum (3 clumps), and no Sedum, with 5 replicates for each treatment (Total $=30$ modules) (Figure 1). Uniform-distribution and clumped-distribution Sedum modules were planted with the same number of Sedum shoots. In accordance with extensive green roof management [38], modules were neither irrigated nor fertilized throughout the duration of the experiment. The sampling across the experimental modules was meant to test the response of arthropod communities to different setups of green roofs.

Each of the experimental modules containing annuals was seeded with a total of 1000 seeds- 50 seeds from each of the 20 species (Figure 2) (Table 1). Seeds were mixed in a bucket with $5 \mathrm{~L}$ of the module substrate and then evenly distributed over the module. Modules were covered with a $2 \mathrm{~cm}$ layer of medium-sized (6-20 mm) gravel.

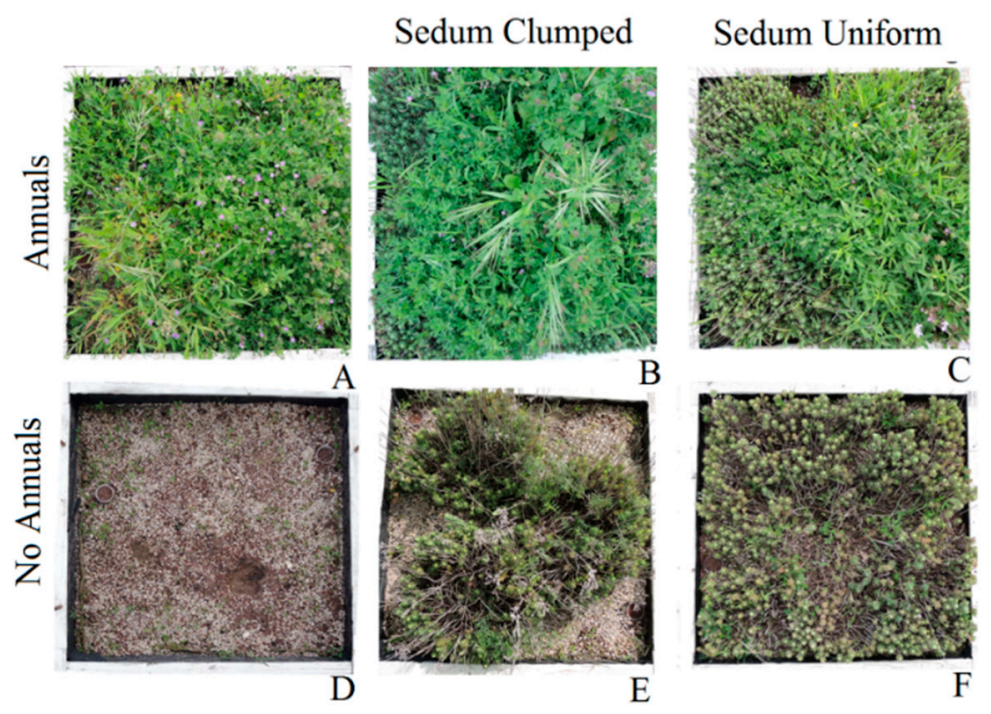

Figure 1. Design of the experimental modules. (A) Annuals only, (B) annuals and Sedum clumped, (C) annuals and Sedum uniform, (D) no annuals and no Sedum, (E) Sedum clumped, (F) Sedum uniform. 


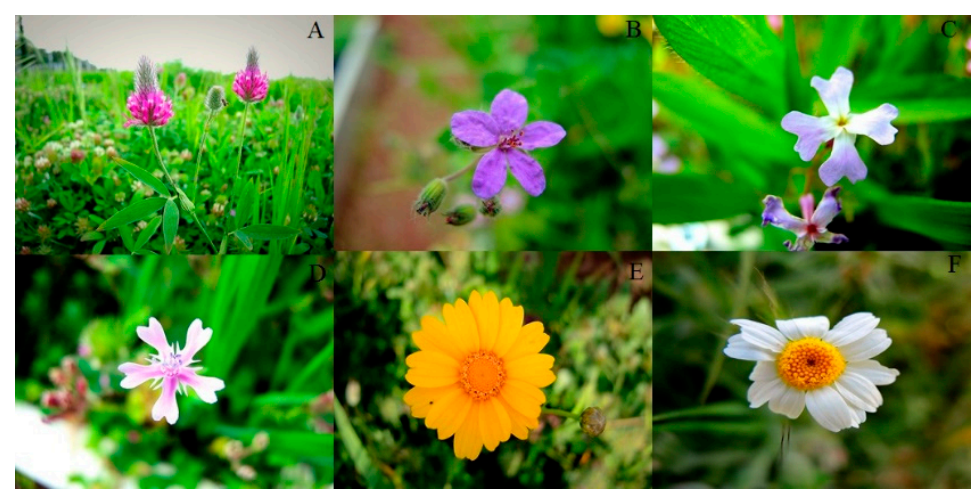

Figure 2. Some of the annual plants from the experimental modules. (A) Trifolium purpureum Loisel. (B) Erodium malacoides (L.) L'Her. (C) Ricotia lunaria (L.) DC. (D) Silene aegyptiaca (L.) L. f. (E) Chrysanthemum coronarium (L.) NN Tzvel. (F) Anthemis pseudocotula Boiss.

Table 1. List of plant species observed from the experimental modules from February to May 2018.

\begin{tabular}{cc}
\hline Species & Family \\
\hline Trifolium purpureum Loisel. & Papilionaceae \\
Erodium malacoides (L.) L'Her. & Geraniaceae \\
Ricotia lunaria (L.) DC. & Cruciferae \\
Silene aegyptiaca (L.) L. f. & Caryophyllaceae \\
Chrysanthemum coronarium (L.) NN Tzvel. & Compositae \\
Anthemis pseudocotula Boiss. & Compositae \\
Stipa capensis Thunb. & Gramineae \\
Trifolium stellatum L. & Papilionaceae \\
Malva parviflora L. Graebn.) Schweinf. & Gramineae \\
Triticum dicoccoides (Koern. Ex Asch. \& & Malvaceae \\
Avena sterilis L. & Gramineae \\
Hordeum geniculatum All. & Gramineae \\
Sedum sediforme (Jacq.) Pau & Gramineae \\
\hline
\end{tabular}

\subsection{Vegetation Cover and Vegetation Structure Analysis}

Vegetation cover was measured using digital photos (brand: Nikon Coolpix p7700). Photos were taken on sunny days from February to May 2018 in the morning hours (09:30-12:00). The digital camera was placed in vertical placement at around $1.5 \mathrm{~m}$ from the experimental module. Pictures were then analyzed using the Canopeo application on Matlab. The Canopeo application is based on color ratios-from red to green and blue to green - and an excess green index [39]. The result of each analysis is a binary image where white pixels correspond to the pixels that satisfied the selection criteria (green canopy) and black pixels correspond to the pixels that did not meet the selection criteria (not green canopy) (see Figure 3). To determine foliage height diversity, 25 poles were erected up to the highest point of the tallest plant in each experimental module. We counted the number of times each pole made contact with a leaf [40] within several vertical layers $(0-10 \mathrm{~cm}, 10-20 \mathrm{~cm}, 20-30 \mathrm{~cm}, 30-40 \mathrm{~cm}$, $40-50 \mathrm{~cm}, 50-60 \mathrm{~cm}, 60+\mathrm{cm}$ ). Vegetation structure (foliage height diversity (FHD)) was measured using the Shannon index [41]:

$$
F H D=H^{\prime}=\Sigma p i \log _{e} p_{i},
$$

where $p_{i}$ is the proportion of the total number of contacts with plants that occur in the $i$ th stratum. This is the index that has been used in the past to measure FHD. $S$ is the total number of strata. 

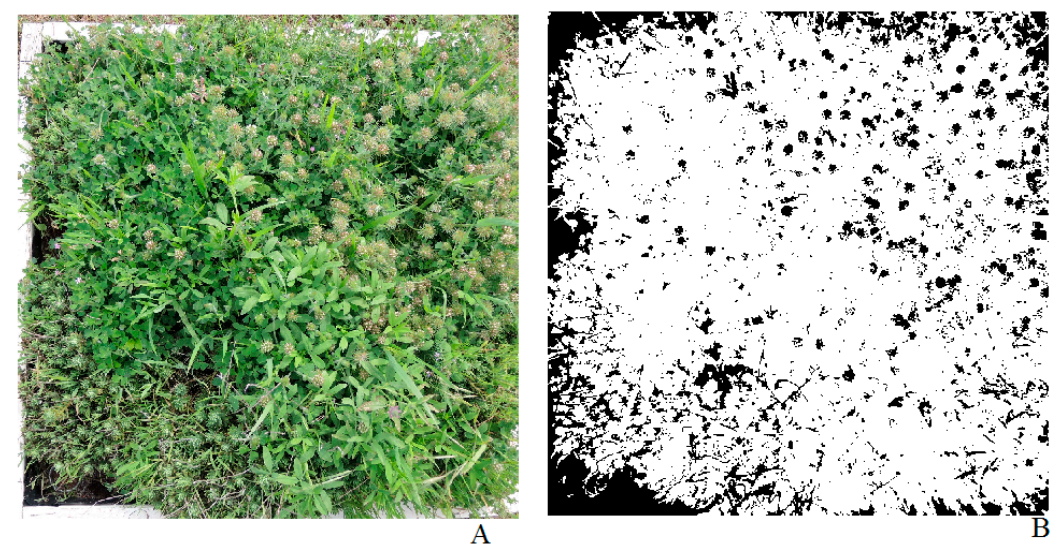

Figure 3. (A) Picture of an experimental module. (B) The experimental module analyzed using Canopeo Matlab (the result is $81.06 \%$ vegetation cover).

\subsection{Substrate Temperature and Relative Substrate Moisture}

Substrate temperatures were measured from February to May 2018 using temperature sensors (Probe thermometer TFA 30.1048). Sensors were placed 5-10 cm deep in soil once a month. Sensors can measure temperatures ranging from -50 to $+300{ }^{\circ} \mathrm{C}$. For relative substrate moisture, we used Soil Moisture-Pro (volumetric sensor). The rapid probe measurements provided a high-resolution sampling component that enabled a more accurate characterization of the mean and variability of the surface soil moisture content with an $\mathrm{ECH}_{2} \mathrm{O}$ EC-5 frequency-domain probe (Decagon Devices Inc., Pullman, WA, USA). Measurements were taken on either side $( \pm 25 \mathrm{~cm})$ of each the experimental modules once a month. Measures were taken to avoid the possible effects of substrate moisture on the accuracy/effectiveness of the temperature measurements.

\subsection{Arthropod Sampling}

The research was properly designed in regard to ethical standards [42]. Arthropods from green roofs were sampled from February to May 2018 using two methods in order to provide a reliable inventory-i.e., (i) pitfall traps and (ii) beating the vegetation combined with a visual search. For pitfall traps, we used 16-ounce translucent plastic cups (70 $\mathrm{mm}$ in diameter and $80 \mathrm{~mm}$ in depth) that were placed inside soil for $\sim 48 \mathrm{~h}$. Two traps were set per plot $(2$ traps $\times 30$ experimental modules $=60$ traps in total). Pitfall traps were dry without the use of any chemical materials. Sample collections from pitfall traps were done twice a month using an insect aspirator. Beating the vegetation and the visual search were only done after collecting from the pitfall traps and closing them. The visual search for arthropods was done using an insect aspirator; the visual search process consisted of a 5 min search from each experimental module. The arthropods collected were put into a $50 \mathrm{~mL}$ falcon tube filled with alcohol and labeled with the following information: date of sampling, plot number, and type of treatment. After the $5 \mathrm{~min}$ visual search, we used a bamboo stick to collect arthropods in plastic containers (length $\times$ width $\times$ height: $22 \times 16 \times 9 \mathrm{~cm}$ ) by beating the vegetation. Samples were collected from the plastic container using an insect aspirator and then placed into separate vials.

\subsection{Data Analysis}

To identify arthropod communities on green roofs, we used the morphospecies approach [43]. Each taxonomic species was assigned to one morphospecies. The morphospecies concept presents a useful tool for conservation, particularly for environmental impact assessment and when inventorying diversity does not require information on particular species. The number of morphospecies was used as a surrogate for the number of taxonomic species [43]. Oliver and Beattie [43] have shown that morphospecies identified by non-specialists can provide estimates of richness and turnover consistent with those generated using species identified by taxonomic specialists. From that, we built a species 
richness index based on the number of species found, and arthropod abundance was based on the number of individuals from each experimental module.

To test for the arthropod response to the different green roof setups and sampling periods, we ran a linear regression analysis to identify predictors that may affect arthropod abundance and richness on green roofs. Normality in all cases was assessed via the Shapiro-Wilks test; $p>0.05$. We also used two-way ANOVA to determine the significance $(p<0.05)$ of the main effects (green roof setups and period of sampling). The analysis was performed in R software [44] using the aov function. The two-way ANOVA analysis was followed by a TUKEY post-hoc test for significant main effects only.

To compare arthropod abundance and richness between the two periods-i.e., the annuals' blooming and withered periods-we used a paired Student's $t$-test, which was performed in $\mathrm{R}$ software using the $t$-test function, on the total number of arthropods (abundance) and the number of species (species richness) of arthropods from the two periods.

\section{Results}

In this study, we recorded 6776 individual arthropods, of which 4401 (65\%) individuals were found during the annuals' blooming period (February and March). This represents an average of 56 individuals per $\mathrm{m}^{2}$ recorded from the whole season, of which an average of 73 individuals per $\mathrm{m}^{2}$ was recorded during the annuals' blooming period. This number drops to 40 individuals during the period in which annuals were withered (April and May). For species richness, an average of 12 species was found to occur per $\mathrm{m}^{2}$ during the annuals' blooming period; this value dropped to 8 species during the annuals' withered period (please refer to Figures 4 and 5 for some of the arthropods observed from the experimental modules).

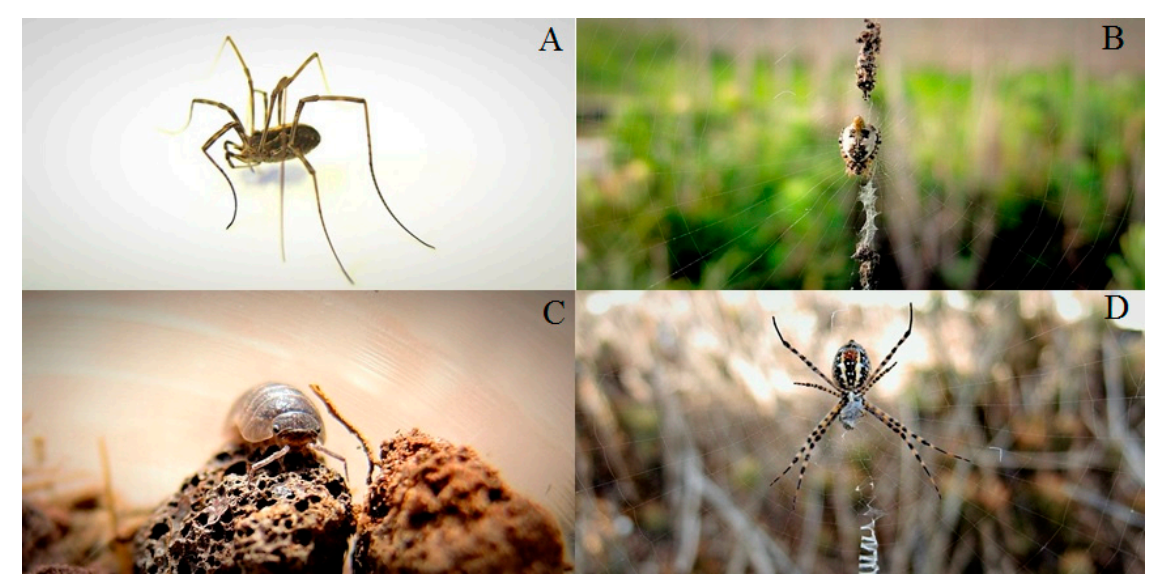

Figure 4. Arthropod taxa observed in the experimental modules: (A) Opiliones Sundevall, 1833; (B) Cyclosa sierra Simon, 1870; (C) Porcellionidae: Agabiformius Verhoeff, 1908; (D) Argiope trifasciata Forsskål, 1775. 


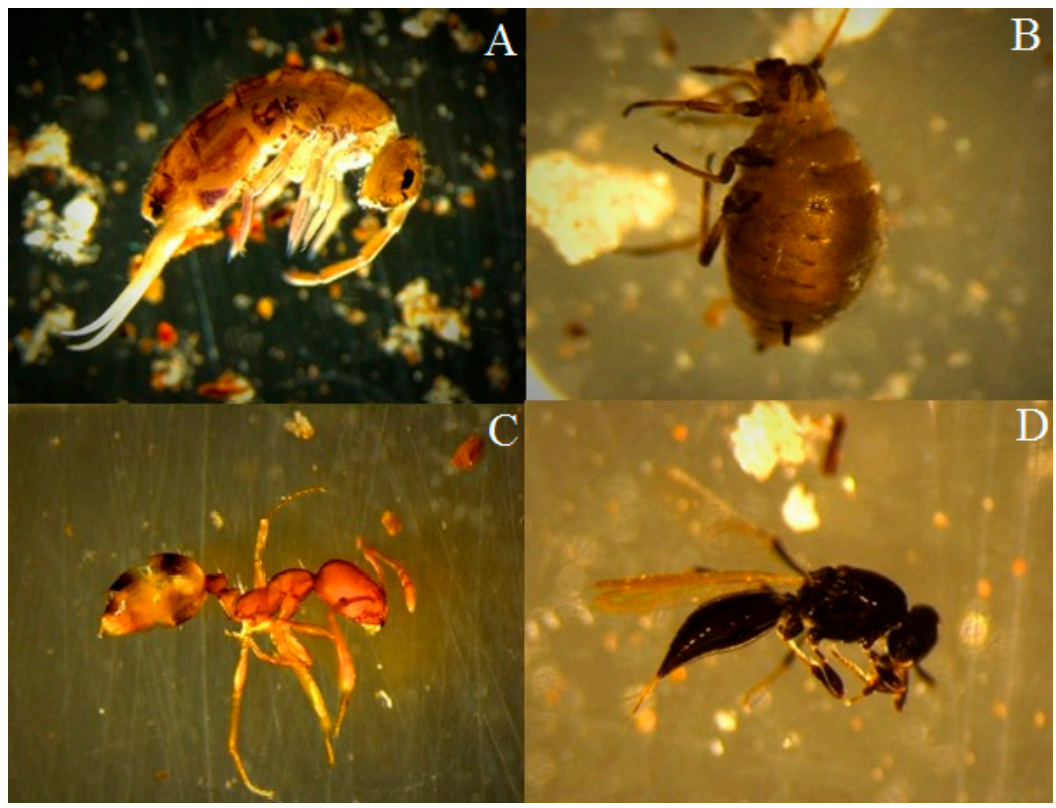

Figure 5. Arthropod taxa observed in the experimental modules: (A) Collembola: Neanuridae Börner, 1901; (B) Aphididae-Chaitophorinae Mordvilko, 1921; (C) Formicidae: Dolichoderinae Forel, 1878; (D) Platygastridae Haliday, 1833.

Arthropod abundance and richness were also affected by green roof setups (treatments). Treatments with only annuals had the highest number of individuals, with an average of 69 individuals and 11 species per $\mathrm{m}^{2}$. Treatments with Sedum and annuals had an average of 61 individuals and 13 species per $\mathrm{m}^{2}$. Treatments without annuals, i.e., Sedum only, had an average of 55 individuals and 9 species per $\mathrm{m}^{2}$. For the control, there was an average of 40 individuals and 4 species per $\mathrm{m}^{2}$.

Prior to testing our hypothesis, a correlation between vegetation structure (foliage height diversity) and vegetation cover was tested. In this study, vegetation structure (foliage height diversity) was positively associated with vegetation cover $\left(p<0.001, \mathrm{R}^{2}=0.8215\right)$ (Figure 6$)$. Hence, for the subsequent analysis, we used vegetation cover as a proxy measure of vegetation structure. For vegetation cover data and the other predictors used in this study-i.e., substrate temperature and substrate relative moisture-refer to Table 2.

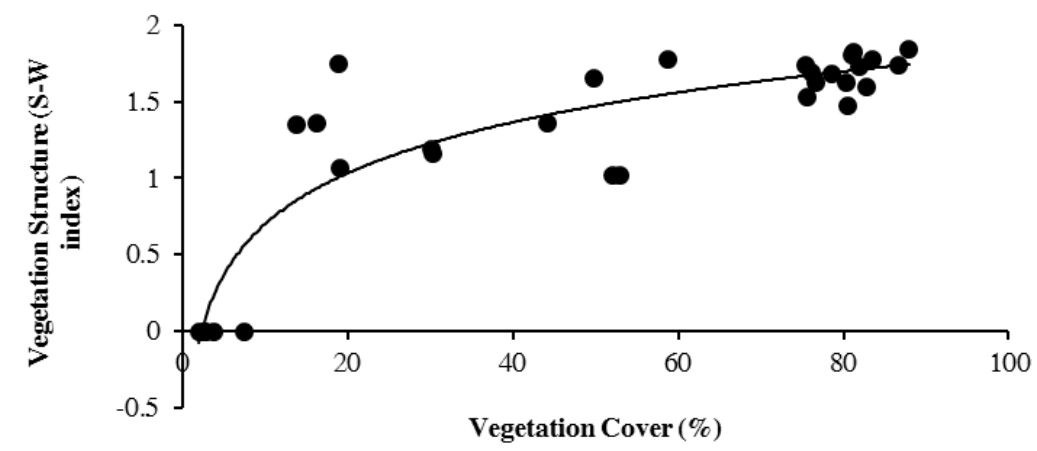

Figure 6. Scatterplot illustrating the significant correlation between vegetation cover (\%) and vegetation structure. $\mathrm{R}^{2}=0.8215, p<0.001$. 
Table 2. The minimum, maximum, median, and $S V$ for substrate temperature, vegetation cover, and substrate moisture from the experimental modules. AC: annuals and Sedum clumped, AE: annuals and no Sedum, AU: annuals and Sedum uniform, EC: no annuals and Sedum clumped, EE: no annuals and no Sedum, EU: no annuals and Sedum uniform, A: blooming period: annuals' blooming period; A: withered period: annuals' withered period.

\begin{tabular}{|c|c|c|c|c|c|c|c|c|c|c|c|c|}
\hline & $\begin{array}{c}\text { Substrate } \\
\text { Temperature } \\
\left({ }^{\circ} \mathrm{C}\right)\end{array}$ & & & & $\begin{array}{l}\text { Tegetatio } \\
\text { Cover }(\%\end{array}$ & & & & $\begin{array}{c}\text { Substrate } \\
\text { Moisture (\%) }\end{array}$ & & & \\
\hline & Min & $\operatorname{Max}$ & Median & $S V$ & Min & Max & Median & $S V$ & Min & Max & Median & $S V$ \\
\hline All & 13.30 & 29.10 & 18.30 & 4.80 & 0.00 & 87.96 & 14.39 & 28.35 & -9.50 & 62.40 & 2.00 & 20.71 \\
\hline$A C$ & 13.9 & 27.7 & 5.03 & 4.85 & 6.59 & 81.06 & 13.95 & 31.50 & -9.1 & 39.5 & -0.20 & 16.50 \\
\hline $\mathrm{AE}$ & 13.7 & 28 & 4.88 & 4.82 & 0 & 87.96 & 14.49 & 34.16 & -5.3 & 50 & 1.10 & 19.60 \\
\hline $\mathrm{AU}$ & 13.8 & 27.9 & 5.17 & 4.60 & 5.95 & 83.39 & 14.49 & 32.15 & -6.9 & 56.5 & 2.80 & 20.75 \\
\hline $\mathrm{EC}$ & 13.3 & 29.1 & 4.98 & 4.64 & 1.55 & 49.8 & 14.28 & 13.79 & -9.5 & 56.2 & 2.70 & 20.81 \\
\hline $\mathrm{EE}$ & 16.5 & 29 & 4.41 & 4.58 & 0.01 & 7.4 & 14.39 & 2.23 & -7.4 & 62.4 & 2.75 & 26.69 \\
\hline EU & 14.6 & 28 & 4.74 & 4.78 & 4.47 & 52.97 & 14.39 & 13.62 & -9.5 & 42.9 & 0.95 & 19.63 \\
\hline A: blooming period & 13.30 & 22.20 & 16.20 & 1.88 & 1.97 & 87.96 & 44.45 & 29.86 & -5.30 & 62.40 & 23.85 & 18.72 \\
\hline A: withered period & 17.10 & 29.10 & 23.35 & 4.38 & 0.00 & 23.35 & 7.17 & 7.34 & -9.50 & 7.90 & -4.35 & 3.86 \\
\hline
\end{tabular}


In the regression analysis, arthropod abundance per meter square was positively associated with the percent of vegetation cover $\left(p=0.009, \mathrm{R}^{2}=0.507\right)$ and negatively associated with substrate temperature $\left(p=0.018, R^{2}=0.443\right)$. Species richness was also positively associated with vegetation cover $\left(p<0.0001, R^{2}=0.899\right)$ (Figure 7). Neither arthropod abundance nor richness was influenced by substrate relative moisture. Surprisingly, these variables also failed to explain body length in arthropods, as no significant relation was found.

Arthropods also varied in abundance and richness greatly during sampling periods and with green roof setups. During annual blooming periods (February and March), there were more arthropod individuals and more species differences between treatments with annuals and without annuals (Figure 8). Treatments that had annuals were found to have a higher number of individuals and higher species richness; this is no surprise since data showed that arthropod abundance and richness were associated with vegetation cover, and the association was maximized during annuals' blooming periods. However, during the annuals' withered period (April and May), treatments with Sedum performed better and had quite a higher number of arthropods (abundance) and a slightly similar number of arthropod species. The two-way ANOVA showed a significant effect of the period in which sampling was conducted on arthropod abundance $\left(\mathrm{F}_{1,108}=22.964, p<0.001\right)$ and also on species richness $\left(\mathrm{F}_{1,108}=77.21, p<0.001\right)$. Arthropod abundance, however, did not show any significant variation according to treatment (green roof setup) $\left(\mathrm{F}_{5,108}=1.36, p=0.259\right)$. Meanwhile, species richness did show a statistically significant difference between treatments $\left(F_{5,108}=30.217\right.$, $p<0.001)$. The interaction between period and treatment showed a significant effect on both arthropod abundance and species richness $\left(\mathrm{F}_{5,108}=4.03, p<0.001\right.$ and $\mathrm{F}_{5,108}=8.64, p<0.001$, respectively) (see Table 3). Post-hoc pairwise comparisons showed that there was a significant difference between plots that were empty and plots that had annuals (Tables 4 and 5). Annuals increased the niche space for arthropods and also provided more resources.

Comparing arthropod abundance and richness between the two observed periods-i.e., annuals' blooming periods and annuals' withered period—showed that arthropod abundance per meter square was significantly different between the two periods (paired $t$-test results were $t(59)=4.120, p<0.001$ ). In addition, a paired $t$-test showed a significant difference in species richness as well (paired $t$-test, $t(59)=7.026, p<0.001)$.

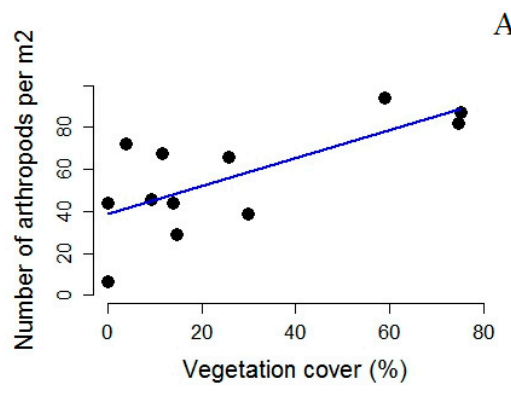

A
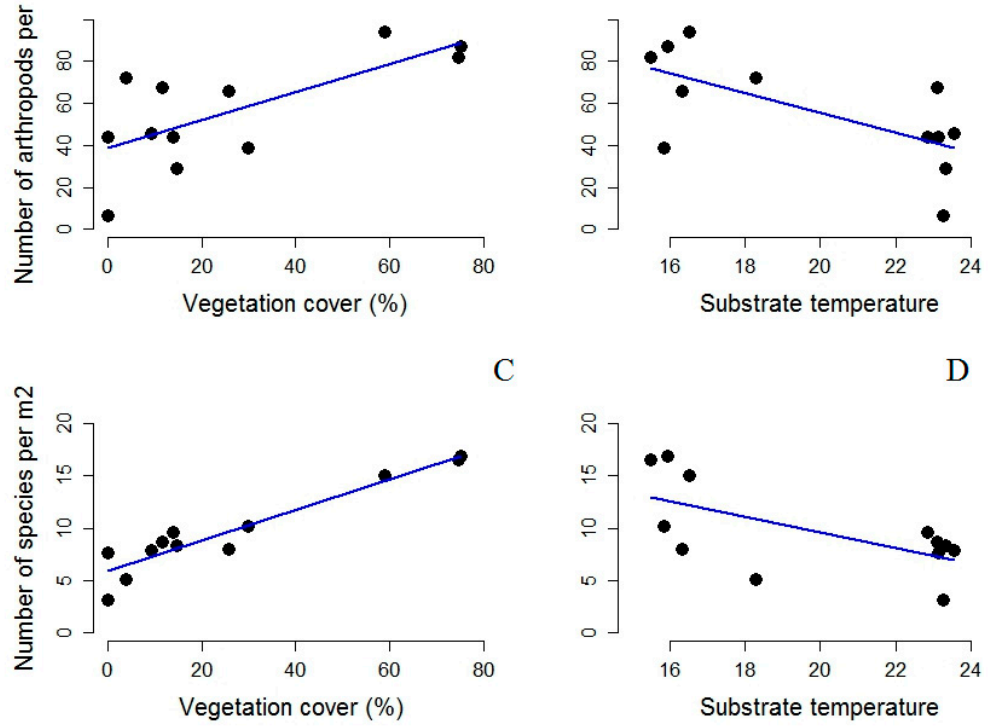

D

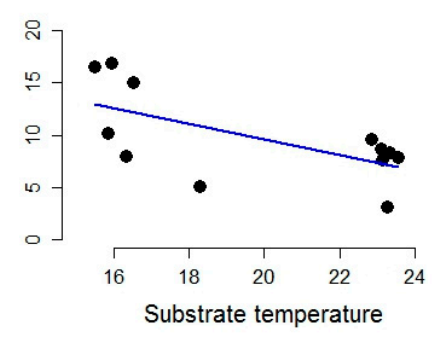

Figure 7. Scatter plots of number of arthropods (abundance) and species richness (number of species) per $\mathrm{m}^{2}$ as response variables plotted against $(\mathbf{A}, \mathbf{C})$ vegetation cover (proxies of vegetation structure/diversity) and (B,D) substrate temperature. Regression lines are given for statistically significant variables $(p<0.05)$. 

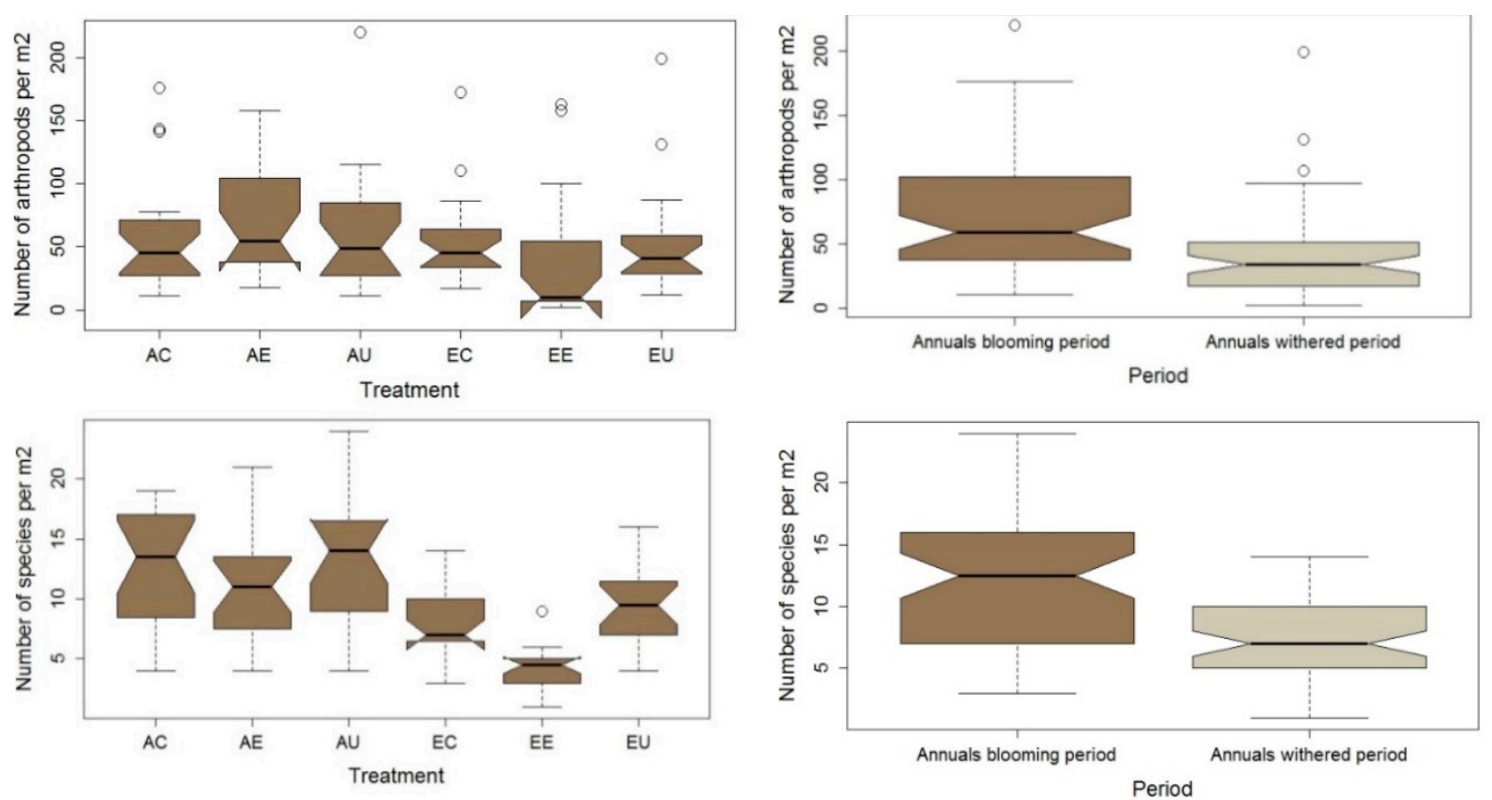

Figure 8. Boxplots represent the number of arthropods (abundance) and number species per $\mathrm{m}^{2}$ from the different experiment modules during the season of 2018 at the University of Haifa. The box shows the interquartile range; the line shows the median of the data; and the notch displays the confidence interval around the median, which is normally based on the median, $+/-1.57 \times \mathrm{IQR} / \mathrm{sqrt}$ of $\mathrm{n}$. AC: annuals and Sedum clumped, AE: annuals and no Sedum, AU: annuals and Sedum uniform, EC: no annuals and Sedum clumped, EE: no annuals and no Sedum, EU: no annuals and Sedum uniform.

Table 3. Two-way ANOVA analysis in R software using two independent variables-period during the season (annuals' blooming or withered periods) and treatments (green roof setups) - and two dependent variables—species richness and abundance.

\begin{tabular}{cccccc}
\hline & df & Sum sq. & Mean sq. & F-Value & Pr $(>\mathbf{F})$ \\
\hline Arthropod abundance & & & & & \\
\hline Period & 1 & 34,206 & 34,206 & 22.964 & $<0.0001$ \\
Treatment & 5 & 10,129 & 2026 & 1.360 & 0.245 \\
Period: Treatment & 5 & 29,992 & 5998 & 4.027 & 0.002 \\
Residuals & 108 & 160,868 & 1490 & & \\
\hline Species richness & & & & & \\
\hline Period & 1 & 580.8 & 580.8 & 77.211 & $<0.00$ \\
Treatment & 5 & 1136.5 & 227.3 & 30.217 & $<000$ \\
Period: Treatment & 5 & 324.8 & 65.0 & 8.636 & $<0.001$ \\
Residuals & 108 & 812.4 & 7.5 & & \\
\hline
\end{tabular}

Table 4. Post-hoc pairwise comparisons of annual blooming and annual withered period.

\begin{tabular}{ccccc}
\hline \multicolumn{5}{c}{ Annuals Blooming-Withered Period } \\
\hline & diff & Lower & Upper & $p$ adj \\
\hline Arthropod abundance & -33.766 & -47.733 & -19.799 & $<0.0001$ \\
\hline Species richness & -4.4 & -5.392 & -3.407 & 0 \\
\hline
\end{tabular}


Table 5. Post-hoc pairwise comparison for species richness per treatment $\left.{ }^{* *} p<0.05\right)$. AC: annuals and Sedum clumped, AE: annuals and no Sedum, AU: annuals and Sedum uniform, EC: no annuals and Sedum clumped, EE: no annuals and no Sedum, EU: no annuals and Sedum uniform.

\begin{tabular}{ccccc}
\hline Treatments & diff & lwr & upr & $p$ adj \\
\hline EE-AC & -8.50 & -11.02 & -5.98 & $0.00^{* *}$ \\
EE-AE & -7.25 & -9.77 & -4.73 & $0.00^{* *}$ \\
EE-AU & -8.95 & -11.47 & -6.43 & $0.00^{* *}$ \\
EU-EE & 5.35 & 2.83 & 7.87 & $0.00^{* *}$ \\
EC-AU & -5.10 & -7.62 & -2.58 & $0.00^{* *}$ \\
EC-AC & -4.65 & -7.17 & -2.13 & $0.00^{* *}$ \\
EE-EC & -3.85 & -6.37 & -1.33 & $0.00^{* *}$ \\
EU-AU & -3.60 & -6.12 & -1.08 & $0.00^{* *}$ \\
EC-AE & -3.40 & -5.92 & -0.88 & $0.00^{* *}$ \\
EU-AC & -3.15 & -5.67 & -0.63 & $0.01^{* *}$ \\
EU-AE & -1.90 & -4.42 & 0.62 & 0.25 \\
AU-AE & 1.70 & -0.82 & 4.22 & 0.37 \\
EU-EC & 1.50 & -1.02 & 4.02 & 0.52 \\
AE-AC & -1.25 & -3.77 & 1.27 & 0.70 \\
AU-AC & 0.45 & -2.07 & 2.97 & 1.00 \\
\hline
\end{tabular}

\section{Discussion}

The aim of this study was to investigate how the structural complexity of different plant forms can affect the abundance and richness of arthropods on green roofs. We expected that arthropod abundance and richness would increase with increasing structural complexity of different plant forms on green roofs. We found that arthropod abundance and richness were positively associated with the percent of vegetation cover, which was taken as a proxy measure for the vegetation structure/diversity. We also found that neither arthropod abundance nor richness was influenced by the relative moisture of substrate. There was no significant effect of the period in which sampling was conducted on arthropod abundance. However, species richness did show a statistically significant difference between treatments. The effect on arthropod communities was shown to be generated mainly from the vegetation systems (i.e., structural attributes, plant architecture, and phonology), as described by Liu et al. [45] and Kyrö et al. [8]. The result of this study supports our hypothesis that an increased structural diversity due to the coexistence of different life forms of plants on roofs is positively related to the abundance and richness of arthropods. Similar patterns were observed in several studies in the literature. For instance, Greenstone [46] showed that web spider species diversity is highly significantly correlated with vegetation tip height diversity. In another study, Docherty and Leather [47] surveyed the role of stands of different pine species as habitats of spiders and harvestmen. They found that Scots pine plots were morphologically and structurally more complex than lodgepole pine plots. More species of spiders and harvestmen were found in Scots pine than lodgepole pine plots. However, no differences in the abundance of harvestmen were found to occur between the Scots and lodgepole canopies.

\section{Plant Selection and Temporal Variation}

The outcomes from this investigation illustrate how critical plant species selection is for the planning of unirrigated extensive green rooftops, which might be coordinated by several factors, including substrate type, substrate depth, and drought conditions. Proper establishment is critical to the long-term viability of green roof plant cover. Increased vegetation cover on green roofs may be related to higher nutrient availability [48] and can improve the habitat for arthropods. Vegetation cover may also provide shelter for arthropod species [49]. Arthropod abundance and richness showed a strong seasonality, as they both increased during the annuals' blooming period in comparison to the annuals' withered period. Vegetation cover not only affects arthropod communities on green roofs, so it may have several other advantages. For instance, higher percentages of vegetation cover 
will protect the green roof substrate from wind erosion. Since evapotranspiration rates will increase with more vegetation established on the green roof, the faster vegetation is established, the faster the increase in retention rates potentially observed.

Green roof substrates, however, may provide an unstable environment for several plant species due to a tendency toward temperature fluctuations in the substrate [19], which may influence arthropod communities greatly. Temporal stability of vegetation cover in such drought-prone habitats is very critical to enhancing arthropod communities on green roofs. Temporal stability of vegetation can be achieved by the addition of artificial water sources-i.e., irrigation systems. Lundholm et al. [50] showed that the temporal stability of aboveground biomass was maximized in treatments containing succulent groups. In our study, Sedum plants influenced aboveground biomass greatly during the annuals' blooming period. However, this effect seems to have diminished over time.

Long-term evaluations of plants and arthropods are needed for living roofs that may help provide temporal stability of urban biodiversity. In addition, further investigation is needed to compare the outcome of this study with those of irrigated roofs. We conclude that the results of this study are relevant to the planning and design of green roofs in order to enhance the arthropod community in urban areas.

Author Contributions: Designed research, I.N.A.S.; performed research, I.N.A.S.; analyzed data, I.N.A.S.; writing-original draft, I.N.A.S.; writing-review and editing, L.B. and I.N.A.S.; supervision, L.B.; funding acquisition, L.B.

Funding: This research was funded by Peter and Gyongyver Kadas.

Acknowledgments: We thank Peter and Gyongyver Kadas for providing funding. We also thank Bracha Schindler, Omar Bawab, Harel Agra and Rael Horwitz for helpful feedbacks during this study. This study was part of PhD dissertation on studying the effect of plant selection and quality on enhancing arthropod abundance and richness on green roofs.

Conflicts of Interest: The authors declare no conflicts of interest.

\section{References}

1. Ripple, W.J.; Wolf, C.; Newsome, T.M.; Galetti, M.; Alamgir, M.; Crist, E.; Mahmoud, M.I.; Laurance, W.F.; 15,364 Scientist Signatories from 184 Countries. World scientists' warning to humanity: A second notice. BioScience 2017, 67, 1026-1028. [CrossRef]

2. Aronson, M.F.; La Sorte, F.A.; Nilon, C.H.; Katti, M.; Goddard, M.A.; Lepczyk, C.A.; Warren, P.S.; Williams, N.S.; Cilliers, S.; Clarkson, B.; et al. A global analysis of the impacts of urbanization on bird and plant diversity reveals key anthropogenic drivers. Proc. R. Soc. B 2014, 281. [CrossRef] [PubMed]

3. Shwartz, A.; Turbé, A.; Julliard, R.; Simon, L.; Prévot, A.C. Outstanding challenges for urban conservation research and action. Glob. Environ. Chang. 2014, 28, 39-49. [CrossRef]

4. Jules, E.S. Dangers in dividing conservation biology and agroecology. Conserv. Biol. 1997, 11, 1272-1273.

5. Marzluff, J.M. Worldwide urbanization and its effects on birds. In Avian Ecology and Conservation in an Urbanizing World; Springer: Boston, MA, USA, 2001; pp. $19-47$.

6. Wolff, P.J.; DeGregorio, B.A.; Rodriguez-Cruz, V.; Mulero-Oliveras, E.; Sperry, J.H. Bird Community Assemblage and Distribution in a Tropical, Urban Ecosystem of Puerto Rico. Trop. Conserv. Sci. 2018, 11. [CrossRef]

7. Kadas, G. Rare invertebrates colonizing green roofs in London. Urban Habitat. 2006, 4, 66-86.

8. Kyrö, K.; Brenneisen, S.; Kotze, D.J.; Szallies, A.; Gerner, M.; Lehvävirta, S. Local habitat characteristics have a stronger effect than the surrounding urban landscape on beetle communities on green roofs. Urban For. Urban Green. 2018, 29, 122-130. [CrossRef]

9. McKinney, M.L. Urbanization as a major cause of biotic homogenization. Biol. Conserv. 2006, 127, 247-260. [CrossRef]

10. Cardoso, P.; Erwin, T.L.; Borges, P.A.; New, T.R. The seven impediments in invertebrate conservation and how to overcome them. Biol. Conserv. 2011, 144, 2647-2655. [CrossRef]

11. González-Megías, A.; Gómez, J.M.; Sánchez-Piñero, F. Spatio-temporal change in the relationship between habitat heterogeneity and species diversity. Acta Oecol. 2011, 37, 179-186. [CrossRef] 
12. Perner, J.; Wytrykush, C.; Kahmen, A.; Buchmann, N.; Egerer, I.; Creutzburg, S.; Odat, N.; Audorff, V.; Weisser, W.W. Effects of plant diversity, plant productivity and habitat parameters on arthropod abundance in montane European grasslands. Ecography 2005, 28, 429-442. [CrossRef]

13. Collins, R.; Schaafsma, M.; Hudson, M.D. The value of green walls to urban biodiversity. Land Use Policy 2017, 64, 114-123. [CrossRef]

14. Salman, N.A.I.; Schindler, B.; Agra, H.; Bawab, O.; Friedman-Heiman, A.; Kadas, G.J.; Seifan, M.; Blaustein, L. Green roof research towards enhancing urban biodiversity, storm-water retention and air pollution abatement. CAB Rev. 2018, 13, 1-14.

15. MacIvor, J.S.; Ksiazek, K. Invertebrates on green roofs. In Green Roof Ecosystems; Springer: Cham, Switzerland, 2015; pp. 333-355.

16. MacIvor, J.S.; Lundholm, J. Insect species composition and diversity on intensive green roofs and adjacent level-ground habitats. Urban Ecosyst. 2011, 14, 225-241. [CrossRef]

17. Williams, N.S.; Lundholm, J.; Scott MacIvor, J. Do green roofs help urban biodiversity conservation? J. Appl. Ecol. 2014, 51, 1643-1649. [CrossRef]

18. Getter, K.L.; Rowe, D.B. The role of extensive green roofs in sustainable development. HortScience 2006, 41, 1276-1285.

19. Boivin, M.A.; Lamy, M.P.; Gosselin, A.; Dansereau, B. Effect of artificial substrate depth on freezing injury of six herbaceous perennials grown in a green roof system. HortTechnology 2001, 11, 409-412.

20. Lundholm, J.T. Green roofs and facades: A habitat template approach. Urban Habitat. 2006, 4, 87-101.

21. Cook-Patton, S.C.; Bauerle, T.L. Potential benefits of plant diversity on vegetated roofs: A literature review. J. Environ. Manag. 2012, 106, 85-92. [CrossRef] [PubMed]

22. Köhler, M. Long-term vegetation research on two extensive green roofs in Berlin. Urban Habitat. 2006, 4, 3-26.

23. Durhman, A.K.; Rowe, D.B.; Rugh, C.L. Effect of substrate depth on initial growth, coverage, and survival of 25 succulent green roof plant taxa. HortScience 2007, 42, 588-595.

24. Sayed, O.H. Crassulacean acid metabolism 1975-2000, a check list. Photosynthetica 2001, 39, 339-352. [CrossRef]

25. Emilsson, T. Vegetation development on extensive vegetated green roofs: Influence of substrate composition, establishment method and species mix. Ecol. Eng. 2008, 33, 265-277. [CrossRef]

26. Dirks, I.; Raviv, B.; Shelef, O.; Hill, A.; Eppel, A.; Aidoo, M.K.; Hoefgen, B.; Rapaport, T.; Gil, H.; Geta, E.; et al. Green roofs: What can we learn from desert plants? Isr. J. Ecol. Evol. 2016, 62, 58-67. [CrossRef]

27. Snodgrass, E.C.; Snodgrass, L.L. Green Roof Plants: A Resource and Planting Guide; (No. 04; SB419. 5, S5.); Timber Press: Portland, OR, USA, 2006.

28. Vasl, A.; Shalom, H.; Kadas, G.J.; Blaustein, L. Sedum-Annual plant interactions on green roofs: Facilitation, competition and exclusion. Ecol. Eng. 2017, 108, 318-329. [CrossRef]

29. Butler, C.; Orians, C.M. Sedum cools soil and can improve neighboring plant performance during water deficit on a green roof. Ecol. Eng. 2011, 37, 1796-1803. [CrossRef]

30. Dunnett, N.; Nagase, A.; Booth, R.; Grime, P. Influence of vegetation composition on runoff in two simulated green roof experiments. Urban Ecosyst. 2008, 11, 385-398. [CrossRef]

31. Heinze, W. Results of an experiment on extensive growth of vegetation on roofs. Rasen Grünflachen Begrünungen 1985, 16, 80-88.

32. Schrader, S.; Böning, M. Soil formation on green roofs and its contribution to urban biodiversity with emphasis on Collembolans. Pedobiologia 2006, 50, 347-356. [CrossRef]

33. Van Mechelen, C.; Dutoit, T.; Hermy, M. Vegetation development on different extensive green roof types in a Mediterranean and temperate maritime climate. Ecol. Eng. 2015, 82, 571-582. [CrossRef]

34. Velázquez, J.; Anza, P.; Gutiérrez, J.; Sánchez, B.; Hernando, A.; García-Abril, A. Planning and selection of green roofs in large urban areas. Application to Madrid metropolitan area. Urban For. Urban Green. 2018. [CrossRef]

35. Gaston, K.J. Species-range size distributions: Products of speciation, extinction and transformation. Philos. Trans. R. Soc. Lond. B Biol. Sci. 1998, 353, 219-230. [CrossRef]

36. Vasl, A. The Effects of Selected Biotic and Abiotic Factors on Extensive Green Roof Plant Community Structure, Haifa, Israel. Ph.D. Thesis, University of Haifa, Haifa, Israel, 2016. 
37. Agra, H.; Klein, T.; Vasl, A.; Shalom, H.; Kadas, G.; Blaustein, L. Sedum-dominated green-roofs in a semi-arid region increase $\mathrm{CO}_{2}$ concentrations during the dry season. Sci. Total Environ. 2017, 584, 1147-1151. [CrossRef] [PubMed]

38. Oberndorfer, E.; Lundholm, J.; Bass, B.; Coffman, R.R.; Doshi, H.; Dunnett, N.; Gaffin, S.; Köhler, M.; Liu, K.K.; Rowe, B. Green roofs as urban ecosystems: Ecological structures, functions, and services. BioScience 2007, 57, 823-833. [CrossRef]

39. Patrignani, A.; Ochsner, T.E. Canopeo: A powerful new tool for measuring fractional green canopy cover. Agron. J. 2015, 107, 2312-2320. [CrossRef]

40. MacArthur, R.H.; MacArthur, J.W. On bird species diversity. Ecology 1961, 42, 594-598. [CrossRef]

41. Shannon, C.E.; Weaver, W. The Mathematical Theory of Communication; University of Illinois Press: Urbana, IL, USA, 1963.

42. Harvey-Clark, C. IACUC challenges in invertebrate research. ILAR J. 2011, 52, 213-220. [CrossRef] [PubMed]

43. Oliver, I.; Beattie, A.J. Invertebrate morphospecies as surrogates for species: A case study. Conserv. Biol. 1996, 10, 99-109. [CrossRef]

44. Team, R.C. R: A Language and Environment for Statistical Computing; R Development Core Team: Vienna, Austria, 2013.

45. Liu, R.; Pen-Mouratov, S.; Steinberger, Y. Shrub cover expressed as an 'arthropod island' in xeric environments. Arthropod-Plant Interact. 2016, 10, 393-402. [CrossRef]

46. Greenstone, M.H. Determinants of web spider species diversity: Vegetation structural diversity vs. prey availability. Oecologia 1984, 62, 299-304. [CrossRef] [PubMed]

47. Docherty, M.; Leather, S.R. Structure and abundance of arachnid communities in Scots and lodgepole pine plantations. For. Ecol. Manag. 1997, 95, 197-207. [CrossRef]

48. Evers, J. Stoffhaushalt und Waldbautechnik bei Erstaufforstungen ehemals landwirtschaftlicher Nutzflächen. Landesanst. Ökologie Bodenordn. For. Nordrh.-Westfal. 2001, 19, 1-241.

49. Groner, E.; Ayal, Y. The interaction between bird predation and plant cover in determining habitat occupancy of darkling beetles. Oikos 2001, 93, 22-31. [CrossRef]

50. Lundholm, J.; MacIvor, J.S.; MacDougall, Z.; Ranalli, M. Plant species and functional group combinations affect green roof ecosystem functions. PLoS ONE 2010, 5, e9677. [CrossRef] [PubMed] 